\title{
Pichia anomala in biocontrol for apples: 20 years of fundamental research and practical applications
}

\author{
Jijakli M. Haïssam
}

Received: 16 November 2010/Accepted: 4 December 2010/Published online: 8 January 2011

(C) Springer Science+Business Media B.V. 2011

\begin{abstract}
Fungal pathogens such as Botrytis cinerea, Penicillium expansum and the Gloeosporioides group are mainly responsible for important economical losses of post-harvest apples. Application of biological control agents (BCAs) is an emerging alternative to synthetic fungicides. However, before becoming an economically feasible alternative to chemical control, BCAs have to satisfy different requirements related to biological, technological and toxicological properties. The different steps for a successful strategy of disease control (selection, production and formulation, study of mechanisms of action, ecological characterization, molecular monitoring, pilot efficacy trials, registration) are reviewed in this paper considering the antagonistic yeast Pichia anomala strain $\mathrm{K}$. This strain was selected for its high and reliable antagonistic activity against $B$. cinerea and $P$. expansum on apples. The studies of mode of action and ecological fitness are emphasized because they can lead to a better efficacy of strain K. Recently advanced molecular techniques have contributed to improving knowledge on the modes of action. Thanks to the identification of genes involved in biocontrol properties, the genetic basis of action mechanisms can be understood. That approach was adopted for $P$.
\end{abstract}

J. M. Haissam ( $\)$

Gembloux Agro-Biotech, Plant Pathology Unit, Passage des Déportés, University of Liege, 5030 Gembloux, Belgium

e-mail: jijakli.h@fsagx.ac.be anomala strain $\mathrm{K}$ and led to the identification of genes coding for exo- $\beta$-1,3-glucanases implicated in the efficacy. Based on that identification, a formulation involving $\beta$-1,3-glucans was developed and applied with higher efficacy in controlled conditions. The importance of ecological characterisation is also highlighted in the context of pre-harvest application of $P$. anomala strain $\mathrm{K}$. UV light, temperature and humidity were identified as major factors influencing the strain $\mathrm{K}$ population. A model taking into consideration temperature and humidity was developed and could be useful in deciding whether pre-harvest treatment is sufficient to allow fast colonization of wounds prior to the arrival of wound pathogens, or whether it is wise to apply further post-harvest treatment to increase the yeast population density. This summary presenting 20 years of work also paid attention to practical application of strain $\mathrm{K}$ and its integration with other methods of control.

Keywords Pichia anomala - Botrytis - Penicillium . Biological control · Apples $\cdot$ Post-harvest

Post-harvest diseases of fruits: a predilection field for biological control

Despite modern storage facilities, losses from 5 to $25 \%$ of apples and pears are still being recorded in 
storage rooms. Fungal pathogens such as Botrytis cinerea, Penicillium expansum and Gloeosporioides group are mainly responsible of important economical losses. Control measures of post-harvest apples and pears are still principally based on the protection of fruits from pre- and post-harvest infection with pre- and post-harvest fungicide treatments. However, in the context of consumer reluctance to accept chemical residues in food and public concern for environmental safety, there is an increasing demand to develop alternative methods to control diseases. That demand becomes a critical need with respect to the deregistration of effective and widely used fungicides and the development of fungicide-resistant strains of post-harvest pathogens.

Biological control is generating a great enthusiasm to play a role in sustainable agriculture although the relevance of biological control agents (BCAs) in plant pathology appears limited until now. In this respect, post-harvest biological control could be considered as specially promising on a practical point of view because: (1) The application sites are limited to the harvested commodities, (2) The environmental conditions are defined and stable in storage rooms, (3) The harvested commodities are of high value.

Scientific literature presents numerous examples of biocontrol of fruit diseases (for a review see Janisiewicz and Kosten 2002). Most of the BCAs are yeasts followed by bacteria whereas only few species belong to mycelial fungi. All the potential BCAs are active against post-harvest pathogens of tropical and/ or temperate fruits (including tomato fruits). Apples and citrus are the most prevalent studied fruits. BCAs are targeting mainly the post-harvest diseases infecting fruits thorough wounds (such as B. cinerea, P. expansum, Rhizopus spp.). However, some BCAs are also able to protect fungal pathogens which infect fruits or inflorescences via intact host surface (such as Colletotrichum gloeosporioides). Latent infections are not mentioned to be controlled by BCAs.

Table 1 presents the biopesticides (formulated BCAs) targeting post-harvest diseases already on the market. Three bacteria and four yeasts are registered. Among the bacteria, Pseudomonas syringae strains are specially directed against post-harvest diseases while a Bacillus subtilis strain is also efficient against pre-harvest diseases. Formulations

Table 1 Commercially available biological control products to manage post-harvest fruits diseases

\begin{tabular}{|c|c|c|c|c|}
\hline $\begin{array}{l}\text { Microorganism(s) } \\
\text { contained }\end{array}$ & $\begin{array}{l}\text { Product } \\
\text { trade name }\end{array}$ & Fungal disease target & Crop & $\begin{array}{l}\text { Manufacturer or distributor/ } \\
\text { countries with registration }\end{array}$ \\
\hline $\begin{array}{l}\text { Bacillus subtilis } \\
\text { QST713 }\end{array}$ & $\begin{array}{l}\text { Serenade/ } \\
\text { rhapsody/ } \\
\text { Sereande } \\
\text { garden }\end{array}$ & $\begin{array}{l}\text { Powdery mildew, downy mildew, } \\
\text { Cercospora leaf spot, early blight, } \\
\text { late blight, brown rot, fire blight, and } \\
\text { others }\end{array}$ & $\begin{array}{l}\text { Cucurbits, grapes, hops, } \\
\text { vegetables, peanuts, } \\
\text { pome fruits, stone } \\
\text { fruits, and others }\end{array}$ & $\begin{array}{l}\text { AgraQuest (CA, USA)/ } \\
\text { European community, USA, } \\
\text { Canada }\end{array}$ \\
\hline $\begin{array}{l}\text { Pseudomonas } \\
\text { syringae ESC-10 }\end{array}$ & $\begin{array}{l}\text { Bio-Save } \\
\text { 10LP }\end{array}$ & $\begin{array}{l}\text { B. cinerea, Penicillium spp., Mucor } \\
\text { pyroformis, Geotrichum candidum }\end{array}$ & $\begin{array}{l}\text { Pome fruit, citrus, } \\
\text { cherries, and potatoes }\end{array}$ & $\begin{array}{l}\text { EcoScience Corp. (Longwoord, } \\
\text { FL)/USA }\end{array}$ \\
\hline $\begin{array}{l}\text { Pseudomonas } \\
\text { syringae ESC-II }\end{array}$ & $\begin{array}{l}\text { Bio-Save } \\
110\end{array}$ & $\begin{array}{l}\text { B. cinerea, Penicillium spp., Mucor } \\
\text { pyroformis, Geotrichum candidum }\end{array}$ & $\begin{array}{l}\text { Pome fruit, citrus, } \\
\text { cherries, and potatoes }\end{array}$ & $\begin{array}{l}\text { EcoScience Corp. (Longwoord, } \\
\text { FL)/USA }\end{array}$ \\
\hline $\begin{array}{l}\text { Aureobasidium } \\
\text { pullulans }\end{array}$ & $\begin{array}{l}\text { Boni } \\
\text { protect }\end{array}$ & B. cinerea & Pome fruit & $\begin{array}{l}\text { Bio-Protect GmbH belonging to } \\
\text { Bio-Firm from BIOMIN } \\
\text { (Austria)/Germany, In } \\
\text { preparation for Europe }\end{array}$ \\
\hline $\begin{array}{l}\text { Cryptoccocus } \\
\text { albidus }\end{array}$ & Yield plus & B. cinerea and $P$. expansum & Apple and Pear & $\begin{array}{l}\text { Anchor Yeast (South Africa) } \\
\text { belonging to Lallemand } \\
\text { group/South Africa }\end{array}$ \\
\hline $\begin{array}{l}\text { Metschnikowia } \\
\text { fructicola }\end{array}$ & Shemer & $\begin{array}{l}\text { P. digitatum, P.italicum, } \\
\text { P.expansum,B. cinerea, Rhizopus } \\
\text { stolonifer, Aspergillus niger, } \\
\text { Fusarium and Sclerotinia sclerotium }\end{array}$ & $\begin{array}{l}\text { Citrus, pome and stone } \\
\text { fruits, grapes, } \\
\text { strawberries and sweet } \\
\text { potatoes }\end{array}$ & $\begin{array}{l}\text { Agrogreen, belonging to Bayer } \\
\text { group/Israël, in preparation } \\
\text { for Europe }\end{array}$ \\
\hline $\begin{array}{l}\text { Canida oleophila } \\
\text { strain } O\end{array}$ & Nexy & B. cinerea, Penicillium spp. & Pome fruits & $\begin{array}{l}\text { Lesaffre- Bionext (France)/ } \\
\text { Europe }\end{array}$ \\
\hline
\end{tabular}


based from $P$. syringae strains are the oldest on the market and belong to a US company. The Bacillus subtilis product is the only one to be registered both in USA and Europe.

A strain of Aureobasidium pullulans is directed against $B$. cinerea on pome fruits but is also active against fire blight under another commercial trade name. Until now, that strain is only registered in Germany. Metschnikowia fructicola was isolated in Israël and is efficient against post-harvest diseases on various post-harvest commodities. Cryptoccocus albidus and Candida oleophila strain $\mathrm{O}$ are targeting post-harvest diseases of apples and pears. C. albidus is commercialised in South Africa while C. oleophila is registered in US, UK and France and may be sold in these countries.

Pichia anomala is often cited to protect postharvest fruits against wound pathogens but also grains against Penicillium roquefertii (Schnürer and Jonsson 2011). However, before becoming an economically feasible alternative to chemical control, this yeast as any other BCA has to satisfy different requirements related to biological, technological and toxicological properties (Fig. 1). These requirements will be reviewed considering $P$. anomala strain $\mathrm{K}$, a biocontrol agent isolated 20 years ago (Jijakli and Lepoivre 1993).

\section{Isolation and selection of Pichia anomala strain K}

To control post-harvest diseases, investigators usually isolate naturally occurring microorganisms from fruits just before harvesting or during storage (Aloi et al. 1991; Gullino et al. 1991; Janisiewicz 1991). Nevertheless, an absolute relationship between efficacy and origin of isolation doesn't exist. Actually, microorganisms exhibiting antagonistic properties against $B$. cinerea and $P$. expansum have been isolated from soil, leaves of apple trees or from fruits or leaves of other plants (Janisiewicz 1988; Janisiewicz and Roitman 1988; Wilson and Wisniewski 1989). In this respect, an elegant and fast method of antagonist isolation has been adopted by Wilson et al. (1993). They applied rinsing waters from tomatoes and apples directly on wounds inoculated with the pathogen (B. cinerea) and isolated antagonistic microorganisms from wounds which did not exhibit any symptoms.

We isolated microorganisms from rinsing waters of Golden Delicious apples at harvest and after different periods of storage (Jijakli and Lepoivre 1993). Among 329 epiphytic microorganisms (yeasts and bacteria), Pichia anomala (strain K) (Hansen) Kurtzman was selected for its high and reliable biocontrol activity against infection by $B$. cinerea or Penicillium sp. on wounded Golden Delicious (Jijakli and Lepoivre 1993). Treatment of wounded sites with $50 \mu \mathrm{l}$ of yeast suspension $\left(10^{7} \mathrm{CFU} / \mathrm{ml}\right)$ was sufficient to inhibit rot development induced by $50 \mu \mathrm{l}\left(10^{6}\right.$ spores $\left./ \mathrm{ml}\right)$ of either B. cinerea or Pencillium sp. at 5 and $25^{\circ} \mathrm{C}$.

\section{Production of strain $\mathbf{K}$}

When the number of strains of potential candidates is sufficiently reduced, the technological properties with
Fig. 1 Steps leading to the practical use of BCAs (from Jijakli et al. 1999)

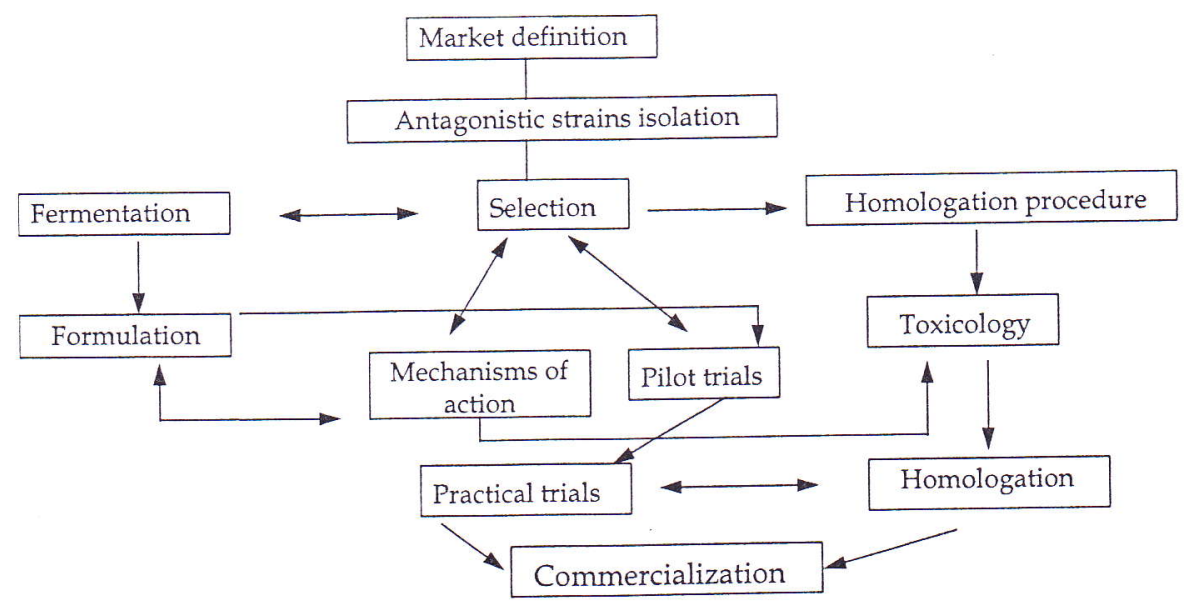

Springer 
regard to amenability for the mass production and the preparation of formulation of the microorganisms must be evaluated. The production and the formulation must lead to a product which has the following characteristics: (1) stable during its storage period, (2) easy to prepare and apply with a standard material, (3) economically affordable for the industry and the fruit grower. The cost production of a microorganism includes the culture media and the energy needed for production and drying process. Appropriate adjuvants relative to the drying process (protectants, carriers,...) must be added to increase the viability of BCAs during the different processes.

$P$. anomala strain $\mathrm{K}$ was tested for its technological properties. The strain was produced in fermentors (media 863) by CWBI (Centre Wallon de BioIndustrie, Gembloux Agro Bio-Tech, Ulg, Belgium) and fermentation product was dried by lyophilisation. The antagonistic strain can be produced in fermentors and dried while maintaining its antagonistic activity (Jijakli et al. 1993b).

\section{The multiple functions of a proper strain $\mathrm{K}$ formulation}

Formulation plays a great part in the stability of a biopesticide (shelf life). In order to achieve this stability goal, protectants are also added to the preparations which should remain active during several months. Often, this stability is maintained in a cold room (towards $4^{\circ} \mathrm{C}$ ) but the viable rate of propagules decreases generally quickly if they are preserved at ambient temperature. This problem of viability preservation and the properties of the inoculum constitute important limitations to the use of biopesticides. To fulfil the requirements of preservation, the producer of microorganisms will be rather inclined to propose a product formulated in dry form. Some products are now able to be preserved during one or two years at $4^{\circ} \mathrm{C}$ such as $P$. anomala strain $\mathrm{K}$ produced and dried by lyophilisation.

Although several formulations are now available on the market, the development of techniques undoubtedly remains slow due to a case-by-case approach. This approach is still too often inspired by the formulation of the chemical compounds which does not necessarily address the criteria imposed by the use of biocontrol methods such as the compatibility of the formulation with the expression of the antagonism of a living microorganism or concerning minimum impact on the environment by the additives of formulations.

Last but not least, a formulation must also stabilize the level of protection brought by the antagonistic strain in an environment which is not always adequate. It can contribute to increasing the survival and the effectiveness of the microorganism and/or allows the reduction of the concentration in antagonists to be applied without affecting the level of protection, thus improving the economic profitability of the product. Nutrients are frequently reported as adjuvants which stimulate or stabilise the protective level of antagonistic strains in post-harvest diseases (Janisiewicz 1994; Janisiewicz et al. 1992). We selected 15 carbohydrates and 16 nitrogenous compounds as potential adjuvants of yeast formulation (Jijakli et al. 1993a). Only one sugar analogous (2deoxy-D-glucose or 2-gluc) showed a protective effect against $B$. cinerea when applied alone and increased the level of protection from about 60 to $90 \%$ when added to $P$. anomala (strain $\mathrm{K}$ ) suspension $\left(10^{5} \mathrm{CFU} / \mathrm{ml}\right)$. The sole application of 2-gluc inhibited also the development of $B$. cinerea on beans (Jejelowo et al. 1988). This analogue of glucose reduced in vitro spore germination and hyphal growth of B. cinerea and P. expansum (Janisiewicz 1994; Jejelowo et al. 1988; Jijakli et al. 1993a) and could act as a competitive inhibitor of glucose metabolism (Janisiewicz 1994).

On the other hand, none of the other nutrients (Lasparagine, L-proline, galactose, mannitol, ribose and sorbitol), selected for their in vitro and in vivo antagonist stimulation or pathogen inhibition either by Janisiewicz et al. (1992) or Harper et al. (1981) enhanced the protective activity of $P$. anomala strain $\mathrm{K}$ in our experiments. These different results show that an effect observed in a specific plant-antagonistpathogen combination is not automatically transposable to another system when the nutrient affects specifically the antagonistic agents. In contrast, when the nutrient has a specific effect on basic metabolism of the pathogen with no subsequent inhibition of the antagonist, we can expect an easier transposition in different systems.

The application of calcium chloride $(20 \mathrm{~g} / \mathrm{l})$ in mixtures with $P$. anomala strain $\mathrm{K}$ enhanced the protective level against $B$. cinerea and Penicillium $\mathrm{sp}$. 
Mclaughin et al. (1990) and Gullino et al. (1991) observed similar results when calcium was applied together with an antagonistic strain. The influence of calcium on increasing the resistance of host tissues is often reported (Conway 1991; Messiaen 1994), while its action on microorganisms is still poorly studied. Nevertheless, the synergistic action of a combined treatment calcium-antagonist led Mclaughlin et al. (1990) to suggest the secretion of new antifungal metabolites by the BCAs.

Certain other additives are intended to protect the microorganisms against the unfavourable environmental factors (relative humidity, UV, temperature, $\mathrm{pH}$ ), other additives aiming at increasing protection by stimulating the mechanisms of action of the biocontrol agent are also employed. As long as the mechanisms of action of the antagonist and its ecological characteristics are not known, this type of formulation remains empirical. In case of $P$. anomala such additives were found after deep studies (covered in relevant sections below).

\section{Challenges in studying BCA modes of action}

Knowledge of the mechanisms of antagonism is crucial for developing successful post-harvest biocontrol strategies. It is necessary in order to (1) optimize the method and timing of application of the antagonist, (2) optimize formulation to enhance antagonist efficacy, (3) rationally select more effective antagonists, and (4) register biocontrol agents for commercial use. Unfortunately, knowledge of the mode of action of many antagonists of post-harvest diseases is limited. The comprehension of the mechanisms of action is hampered by the complex interactions between host-pathogen-antagonist. Moreover, the mechanisms studied in vitro in order to simplify these complex interactions, do not necessarily reflect in situ reality.

Numerous efforts to elucidate the mode of action of post-harvest biocontrol agents indicate that multiple interactions between antagonist, host, pathogen, and other components of fruit natural epiphytic microflora take place at the site of action. For most BCAs, no major mechanism seems to dominate in their biocontrol but rather multiple interactive modes of action. It appears that the mode of action of a BCA could comprise one or several of the following processes: antibiosis, nutrient or site competition, direct interactions between the biocontrol agent and the pathogen, and induced host resistance (Janisiewicz and Kosten 2002; Wilson and Wisnieswski 1994).

\section{A long road to discovery strain $\mathrm{K}$ modes of action}

Experimental evidence for roles of nutrient competition in BCA antagonistic activity relationships is still missing although several studies suggest that competition for nutrients may be important. Some authors (Chalutz et al. 1991; Roberts 1991; Wisniewski et al. 1989) highlighted the ability of antagonists to rapidly multiply at the wounded sites of fruits but without relating this aptitude to their protective activity. Results of other workers (Droby et al. 1989; Wisniewski et al. 1991) showed that the addition of nutrients can restore both the germination of the pathogen and its development on fruits in presence of the antagonist. The ability of $P$. anomala strain $\mathrm{K}$ to colonise the wounds was also investigated in relation with their protective activity against $B$. cinerea on apples and with regard to the in situ conidial germination of $B$. cinerea (Jijakli et al. 1993a). Populations of $P$. anomala (strains K) in wounds increased at $25^{\circ} \mathrm{C}$ to reach a maximum density $(\sim 1 \log$ unit over the initial density) after $12 \mathrm{~h}$ of incubation similarly to the protection level against $B$. cinerea which also reached a maximum after $12 \mathrm{~h}$ of yeast incubation. On the other hand, in situ spore germination of $B$. cinerea was markedly reduced on wounded sites treated with strain $\mathrm{K}$, even when pathogen and yeast were applied simultaneously with no subsequent protection. This suggested that factor(s) other than inhibition of spore germination may be involved in biocontrol effectiveness.

Whatever the experimental conditions, no antibiosis nor induced host resistance was detected as part of the modes of action of $P$. anomala strain $\mathrm{K}$ (unpublished results). On the contrary, mycoparasitism by this yeast has been presumed to explain inhibition of $B$. cinerea on apples on the basis of biochemical studies of its hydrolytic enzyme system. Endo- and exo- $\beta-1,3$-glucanase activities, but no chitinolytic activities, have been detected in culture filtrates of strain K. Specific activities were higher 
when $B$. cinerea cell wall preparation (CWP) constituted the sole source of carbon, rather than glucose or laminarin (Jijakli and Lepoivre 1998). Exo- $\beta$-1,3glucanases (EC 3.2.1.58) act by successive hydrolysis of the glycosidic bonds at the nonreducing ends of $1,3-\beta$-D-glucans, releasing glucose whereas endo- $\beta$ 1,3-glucanases (EC 3.2.1.39) cleave inner bonds of the polymer chain releasing oligosaccharides. $\beta$-1,3glucanase activites of strain $\mathrm{K}$ were found to degrade $B$. cinerea CWP, and the relative proportion of exolytic $\beta$-1,3-glucanase activity was higher on that substrate than on laminarin (Jijakli and Lepoivre 1998). Two bands of enzyme activity were detected in native polyacrylamide gels. The exo- $\beta$-1,3-glucanase presenting the highest specific activity (PaExg2) was purified from culture filtrates of strain K. PaExg2 showed inhibitory effect on germ tube growth and conidial germination (up to $29 \%$ inhibition) of $B$. cinerea, causing morphological changes in germ tubes. Exo- $\beta$-1,3-glucanase activity was also detected in apple wounds treated with strain $\mathrm{K}$. Overall results suggested that exo- $\beta$-1,3-glucanase activity may be involved in the protective effect of $P$. anomala strain $\mathrm{K}$ against $B$. cinerea.

Recent advanced molecular techniques have contributed to the development of innovative alternative tools for improving knowledge on the antagonistic mechanisms of BCAs and for building on insights provided by microbiological, microscopic, and/or biochemical studies. Thanks to the identification of genes involved in biocontrol properties, the genetic basis of action mechanisms can be understood. A first molecular approach called targeted strategy (Massart et al. 2005) was adopted for $P$. anomala (strain K). The targeted strategy requires prior selection of one or a few genes. This selection can be based on preexisting data such as the study of strain $\mathrm{K}$ hydrolytic enzyme system. After PCR amplification with degenerate primers, two genes encoding exo- $\beta$-1,3-glucanases (PAEXG1, accession number AJ002195, and PAEXG2, accession number AJ222862) have been cloned from strain $\mathrm{K}$ genomic DNA and sequenced (Grevesse et al. 2003). However, the authors ruled out the involvement of PAEXG2 in the biocontrol activity of strain $\mathrm{K}$. In order to address the contradiction with that last observation and biochemical data, the contribution of PAEXG1 and PAEXG2 to antagonism of $B$. cinerea by strain $\mathrm{K}$ was investigated. That was realised with the help of paexg I- and paexg2-single-disruption mutants and with a double mutant strain obtained by sequential inactivation of both genes (Friel et al. 2003, 2005). It was demonstrated that the biocontrol efficiency of $P$. anomala strain $\mathrm{K}$ was affected by inactivation of the PAEXG1 gene, the PAEXG2 gene, or both (Friel et al. 2007). Furthermore, the data (Table 2) highlighted the complexity of the antagonistic relationship established within the host-antagonist-pathogen system, because differences in protection level between mutated and wild-type strains were modulated by apple maturity and yeast inoculum size. Both high yeast concentration and maturation appeared to compensate for inactivation of the PAEXGI or $P A E X G 2$ gene. Indeed the mutated strains exerted no protective effect when low concentrations were applied to fresh apple fruit, but their protective effect was similar to that of the parental strain when they were applied to mature apple fruit at medium or high concentration or to fresh apple fruit at high concentration (Table 2). Thus, a higher yeast population (a greater inoculum size) appears to counterbalance the effect of the glucanase-minus mutations (Friel et al. 2007 ). The relative contribution of exo- $\beta$ - 1,3 -glucanases to biocontrol may be greater under conditions where that of other modes of action, such as competition for nutrients or space, is reduced.

Based on the demonstration of involvement of exo- $\beta$-1,3-glucanase in the protective activity of strain $\mathrm{K}$, a formulation involving YGT (name of an adjuvant containing $\beta$-1,3-glucans) was tested at a concentration of $2 \mathrm{~g} / \mathrm{l}$ in controlled conditions. That formation lead to a higher protection percentage (up to $100 \%$ ) than the percentage obtained by the sole strain $\mathrm{K}\left(10^{7} \mathrm{CFU} / \mathrm{ml}\right)$ against both pathogens on apples against $B$. cinerea and $P$. expansum (Jijakli et al. 2002; Lahlali et al. 2009).

A second molecular strategy was undertaken based on an 'open' approach. Such techniques have been used in studies designed mainly to identify genes involved in biocontrol. They notably include cDNA Amplified Fragment Length Polymorphism Analysis (cDNA-AFLP), differential display, and subtractive hybridization. Massart and Jijakli (2006) used cDNAAFLP to identify genes potentially involved in the biological control of $B$. cinerea by $P$. anomala strain Kh5, a haploid strain derived from $P$. anomala strain $\mathrm{K}$. Strain Kh5 was grew in a medium containing either glucose or $B$. cinerea cell walls and eleven 
Table 2 Lesion diameter measured with parental ( $\mathrm{K}$ and KH6) and mutated strains KE1 (paexg1-), KE2 (paexg2-), and KE1E2 (paexg1-, paexg2-) applied to wounded Golden Delicious apple fruit, $24 \mathrm{~h}$ before inoculation with Botrytis cinerea $(5 \times 104$ spores/wound) (from Friel et al. 2007)

\begin{tabular}{llll}
\hline Strain $^{\mathrm{A}}$ & \multicolumn{3}{l}{ Diameter, status } \\
\cline { 2 - 4 } & $\begin{array}{l}10^{3} \mathrm{CFU} / \\
\text { wound }\end{array}$ & $\begin{array}{l}10^{4} \mathrm{CFU} / \\
\text { wound }\end{array}$ & $\begin{array}{l}10^{5} \mathrm{CFU} / \\
\text { wound }\end{array}$ \\
\hline $\mathrm{A} 1$ & & & \\
$\mathrm{~K}$ & $1.06 \mathrm{a}$ & $0.45 \mathrm{a}$ & $0.14 \mathrm{a}$ \\
KH6 & $1.18 \mathrm{a}$ & $0.41 \mathrm{a}$ & $0.37 \mathrm{a}, \mathrm{b}$ \\
KE1 & $3.6 \mathrm{c}$ & $1.17 \mathrm{~b}$ & $0.47 \mathrm{a}, \mathrm{b}$ \\
KE2 & $2.94 \mathrm{~b}$ & $1.69 \mathrm{~b}$ & $0.55 \mathrm{a}, \mathrm{b}$ \\
KE1E2 & $3.38 \mathrm{~b}, \mathrm{c}$ & $1.44 \mathrm{~b}$ & $0.78 \mathrm{~b}$ \\
Control & $3.68 \mathrm{c}$ & $3.68 \mathrm{c}$ & $3.68 \mathrm{c}$ \\
A2 & & & \\
K & $1.04 \mathrm{a}$ & $0.45 \mathrm{a}$ & $0.09 \mathrm{a}$ \\
KH6 & $1.15 \mathrm{a}$ & $0.68 \mathrm{a}$ & $0.11 \mathrm{a}$ \\
KE1 & $2.09 \mathrm{~b}$ & $1.1 \mathrm{a}$ & $0.14 \mathrm{a}$ \\
KE2 & $2.38 \mathrm{~b}$ & $1.2 \mathrm{a}$ & $0.4 \mathrm{a}$ \\
KE1E2 & $2.28 \mathrm{~b}$ & $1.1 \mathrm{a}$ & $0.43 \mathrm{a}$ \\
Control & $3.67 \mathrm{c}$ & $3.67 \mathrm{~b}$ & $3.67 \mathrm{~b}$ \\
\hline
\end{tabular}

Yeasts were inoculated at three different concentrations $\left(10^{3}\right.$ $10^{4}$, and $10^{5} \mathrm{CFU}$ per wound). Five fruits (10 wounds) were used for each combination. For each apple stock and each concentration, values with the same letter are not significantly different (Duncan test, $P<0.05$ )

A Lesion diameter measured with parental (K and KH6) and mutated strains KE1 (paexg1-), KE2 (paexg2-), KE1E2 (paexg1-, paexg2-) applied to wounded Golden Delicious apples, $24 \mathrm{~h}$ before inoculation with $B$. cinerea $(5 \times 104$ spores per wound). Yeasts were inoculated at three different concentrations $\left(10^{3}, 10^{4}\right.$, and $10^{5} \mathrm{CFU}$ per wound). Five apples (10 wounds) were used for each combination. For each apple stock and each concentration, values with the same letter are not significantly different (Duncan test, $P<0.05$ ). Al Fresh apples, $A 2$ Matured apples

cDNA fragments were identified corresponding to genes overexpressed in the presence of $B$. cinerea cell walls and putatively involved in enzyme secretion, the stress response, sensing or transmission of environmental signals, or energy production. The isolation of these genes is a first step leading to a larger study of their further characterization and an enhanced understanding of their role in biological control. In further work, these putative functions should be confirmed by functional complementation, and their role in biocontrol properties investigated by simple or multiple disruption approaches.
The targeted molecular strategy reveals its powerfulness in demonstrating the implication of some genes (such as exo- $\beta$-1,3-glucanases) in the control of $B$. cinerea by $P$. anomala strain $\mathrm{K}$ and to quantify their impact on the efficacy. Together with proteomics and metabolomics, open strategy will help to develop a holistic approach of the modes of action and to understand better their complexity and their regulation.

\section{Development of monitoring tools}

Besides knowledge of the mechanisms of action, monitoring tools need to be developed to study the ecological fitness of $P$. anomala strain $\mathrm{K}$ after treatment on apples. Because the protective effect of strain $\mathrm{K}$ seems to be closely related to its colonisation on the apple surface (Jijakli et al. 1999), assessment of strain K population dynamics will help to interpret and predict biocontrol efficacy in relation to modality of application, formulation and environmental conditions. In addition, identification and quantification of strain $\mathrm{K}$ during and after its mass production and formulation are a prerequisite to establish a quality control procedure for the biofungicide. Monitoring strain $\mathrm{K}$ requires its unambiguous differentiation among the resident micro-flora (including yeast belonging to the same species) and its quantification on the surface of apples. The shortcomings of the biochemical-based typing methods, which depend on phenotypic expression, and the lack of morphological distinction among similar yeasts on Petri dishes, led to the development of more specific identification methods based on DNA sequences. DNA markers minimise the difficulty of type ability and lack of reproducibility common in the use of phenotypic-based methods (Olive and Bean 1999).

The identification of a specific strain $\mathrm{K}$ natural DNA marker was obtained using RAPD (random amplified polymorphic DNA) analysis (De Clercq et al. 2003). SCAR (sequence-characterized amplified region) primers (K1 and $\mathrm{K} 2$ ) were designed and proved to be specific for amplification of a $262 \mathrm{bp}$ $P$. anomala strain K SCAR marker (De Clercq et al. 2003). The identification of that specific SCAR marker was followed by the development of a monitoring method combining dilution plating on a 
semi-selective medium (HST-PDA, contained three fungicides and one antibiotic) and strain-specific identification of colony forming units with the SCAR marker (De Clercq et al. 2003). This mixed monitoring method was then applied on apples treated with strain $\mathrm{K}$ produced in Petri dishes or in bioreactors and compared with the classical plating method. The percentages of white colonies identified as strain $\mathrm{K}$ with the use of the specific SCAR marker were high (between 91 and 100\%). Consequently, this correction did not lead to severe changes in the dilution plating results. However, molecular identification of the colony forming units gives a more valuable result in terms of specificity. Some of the white yeast colonies did not respond to the SCAR primers and were, therefore, considered as contaminants.

As the mixed monitoring method is laborious and time consuming, a second method was developed for $P$. anomala strain $\mathrm{K}$ using a QC-PCR-ELOSA (Quantitative-Competitive Polymerase Chain Reaction using Enzyme-Linked Oligosorbent Assay) with the 262 bp strain K SCAR marker as target. Using that method, it was possible to quantify the number of yeast cells of $P$. anomala strain $\mathrm{K}$ to recover the antagonist from the apple surface (Pujol et al. 2004). The yeast cell numbers that were tested represent a realistic range of strain $\mathrm{K}$ amounts expected on the surface of pre- or post-harvest treated apples (Jijakli et al. 2002). The sensitivity threshold of QC-PCRELOSA applied under practical conditions allowed detection of less than $10^{3}$ yeast cells per apple (Pujol et al. 2004). Using the same technique to recover yeast cells from treated apple surfaces, the sensitivity threshold of the plating method was around $10^{5} \mathrm{CFU} /$ apple (De Clercq et al. 2003). Finally, manipulation time was considerably reduced by means of its automation procedure (Pujol et al. 2004).

\section{Strain K ecological characteristics}

Biocontrol of post-harvest fruit decays is achievable by post-harvest application of antagonists but also by pre-harvest spraying of biocontrol agents in the field (Benbow and Sugar 1999; Korsten et al. 1997; Leibinger et al. 1997; Teixidõ et al. 1998). In the latter practice, the antagonist is applied just before harvest so that it can colonize the fruit surface and any wounds inflicted during harvest before the arrival of wound pathogens (Ippolito and Nigro 2000). Researchers have highlighted the very real practical problem of promoting the effective establishment of prospective antagonists in a natural environment. This can be crucial, limiting the consistency of biocontrol under field conditions and the widespread commercialization of biocontrol agents. The fluctuation of abiotic factors such as temperature, water availability, relative humidity and UV radiation has the greatest impact on the growth and biological proprieties of prospective biocontrol agents (Magan 2001; Teixidõ et al. 1999). Tolerance to such abiotic fluctuations is a prerequisite to successful application of ecologically competent biocontrol agents under field conditions (Elad 1990).

The influence of artificial UV-B radiation on Pichia anomala strain $\mathrm{K}$, was evaluated in vitro and in vivo. The in vitro LD90 values was $1.6 \mathrm{~kJ} / \mathrm{m}^{2}$ (equivalent to $0.69 \mathrm{~h}$ of natural sunlight), whereas in vivo lethal value was $5.76 \mathrm{~kJ} / \mathrm{m}^{2}$ (equivalent to $2.46 \mathrm{~h}$ of natural sunlight). That adverse effect of sunlight on biocontrol agents may require that UV protectants must be included in the agent formulation (Lahlali et al. 2011). Eight UV-protectants were tested alone or in combination with strain K. Lignin or folic acid could reduce yeast mortality caused by UV-B radiation on apple fruit surfaces and increased significantly the ability of strain $\mathrm{K}$ to control the postharvest pathogen $P$. expansum on wounded apple fruit (Lahlali et al. 2011). Further investigations must verify the potential benefit of lignin or folic acid for $\mathrm{UV}$-protection of strain $\mathrm{K}$ in pre-harvest applications.

In vitro and in vivo studies were also undertaken to develop models predicting the combined effects of relative humidity ( $\mathrm{RH} 75-98 \%$ ), temperature $\left(5-25^{\circ} \mathrm{C}\right)$, and initial applied concentration $\left(10^{4}-\right.$ $10^{8} \mathrm{CFU} / \mathrm{ml}$ ) of $P$. anomala strain $\mathrm{K}$ (Lahlali et al. $2008 \mathrm{a}, \mathrm{b})$. Experiments on apple surface were carried out according to a Box-Behnken matrix. Multiple regression analyses showed that the model yielded a good prediction of yeast density. The effect of relative humidity appeared greater than that of temperature. The number of yeast colony-forming units per square centimetre of apple fruit surface increased with increasing relative humidity, temperature, and initial applied yeast concentration. The model predicted that under optimal growth conditions $\left(25^{\circ} \mathrm{C}, 98 \%\right)$, strain $\mathrm{K}$ should reach a density of $10^{4} \mathrm{CFU} / \mathrm{cm}^{2}$ when applied initially at $10^{7} \mathrm{CFU} / \mathrm{ml}$ 
(strain K). Such density is required for protection against pathogens affecting wounded apples in storage (Andrews 1992; McGuire 1994; De Clercq et al. 2003; Lahlali et al. 2008b). Indeed such developed models may help in choosing the concentration of yeast suspensions to be applied in order to achieve on the apple surface a yeast density of at least $10^{4} \mathrm{CFU} /$ $\mathrm{cm}^{2}$. Our model is capable of predicting the yeast population densities on the apple surface $48 \mathrm{~h}$ after field spraying of biocontrol agents (Lahlali et al. $2008 \mathrm{~b}, 2009)$. It might be useful in deciding whether pre-harvest treatment is sufficient to allow fast colonization of wounds inflicted during harvest and packaging, prior to the arrival of wound pathogens, or whether it is wise to apply further post-harvest treatment to increase the yeast population density and thus ensure better protection against post-harvest apple decays arising in the storage room.

\section{Practical applications of Pichia anomala strain K}

The insufficient efficacy of BCAs against postharvest diseases in practical conditions is still an important factor limiting the implementation of biocontrol methods. The storage of commodities constitutes a field where the limits of the biocontrol could be overcome more easily because the environmental parameters of the rooms of storage are well defined and stable in the course of time. In contrast, the variation of the weather conditions explains very often the lack of stable and reproducible effectiveness of biological control methods in the field. The lack of effectiveness can be due to the inadequacy and/or the variations of the environmental conditions limiting the effectiveness of the agents of biological control, but also to the difficulty in maintaining the effectiveness of the antagonist for one sufficiently long period.

In order to evaluate the possibility of applying $P$. anomala strain $\mathrm{K}$ in orchards, its biocontrol efficacy was assessed when the yeast was applied pre- or post-harvest in orchard trials during two successive growing seasons (Lahlali et al. 2009). Temperature, rain, and relative humidity were monitored as well as strain $\mathrm{K}$ population dynamic. Trees of cv. Golden Delicious apples were treated with a powder of strain $\mathrm{K}\left(10^{7} \mathrm{CFU} / \mathrm{ml}\right)$ produced by $\mathrm{CWBI}$ supplemented with $\beta$-1,3-glucans and $\mathrm{Ca}$. This three- component mixture was applied 12,5 , or 2 days before harvest in the first year and 15,7 , or 3 days before harvest in the second year, by spraying at low volume (300 1 ha -1 ) or high volume $(1,000$ 1/ha) (Lahlali et al. 2009).

The first year, the highest reduction (95.2\%) against blue decay was obtained by means of four successive fungicide treatments and the next-highest level $(87.6 \%)$ with pre-harvest high-volume spraying of the three component mixture 12 days before harvest (Table 3 ). The second year, the best results were obtained with post-harvest Sumico (carbendazim $25 \%$ and diethofencarb $25 \%$ ) treatment and postharvest biological treatment, both by dipping the apples, 88.3 and $56.3 \%$ respectively. A density

Table 3 Efficacy of biocontrol agent Pichia anomala strain K and chemical treatments against blue mould in relation to the method and time of application (from Lahlali et al. 2009)

\begin{tabular}{|c|c|c|}
\hline \multirow[t]{2}{*}{ Treatment } & \multicolumn{2}{|c|}{ Infected fruits $(\%)$} \\
\hline & Year 1 & Year 2 \\
\hline \multicolumn{3}{|l|}{ Pre-harvest ${ }^{\mathrm{A}}$} \\
\hline Biological, LVS (12 or 15 days) & $15.0 \mathrm{~d}^{\mathrm{B}, \mathrm{C}}$ & $68.3 \mathrm{c}$ \\
\hline Biological, HVS (12 or 15 days) & $11.3 \mathrm{e}$ & $60.4 \mathrm{~d}$ \\
\hline Biological, LVS (5 or 7 days) & $52.9 \mathrm{bc}$ & $89.6 \mathrm{~b}$ \\
\hline Biological, HVS (5 or 7 days) & $58.9 \mathrm{~b}$ & $94.0 \mathrm{~b}$ \\
\hline Biological, LVS (2 or 3 days) & $53.3 \mathrm{bc}$ & $95.6 \mathrm{~b}$ \\
\hline Biological, HVS ( 2 or 3 days) & $43.3 \mathrm{c}$ & $56.5 \mathrm{e}$ \\
\hline Standard chemical ${ }^{\mathrm{D}}$ & $3.6 \mathrm{f}$ & $51.8 \mathrm{f}$ \\
\hline \multicolumn{3}{|l|}{ Post-harvest } \\
\hline Biological, dipping & $98.4 \mathrm{a}$ & $42.2 \mathrm{~g}$ \\
\hline Biological, drenching & 99.2 a & $43.2 \mathrm{~g}$ \\
\hline Standard chemical ${ }^{\mathrm{E}}$ & $13.0 \mathrm{de}$ & $10.1 \mathrm{~h}$ \\
\hline \multicolumn{3}{|l|}{ Control } \\
\hline Untreated apples & 98.9 a & $98.5 \mathrm{a}$ \\
\hline
\end{tabular}

LVS low volume spray, HVS high-volume spray

A In parentheses: time of treatment in days before harvest (first number, year 1 ; second number, year 2)

B Data are the mean of four replicates of incidence of decayed fruits $(\%)$ calculated based on number of infected fruits as compared to total fruits for each treatment

$C$ This column shows when differences are significant $(P<0.05)$; if two results share a common letter, the difference between them is not significant according to Newman-Keuls test

D Spraying of Bavistin, Phytocap, Sumico, and Euparen at the authorised Belgian doses, respectively $4,3,2$, and 1 week before harvest

E Dipping in Sumico (1 g/l) 
threshold of $1 \times 10^{4} \mathrm{CFU} / \mathrm{cm}^{2}$ of strain $\mathrm{K}$ on the apple surface seemed to be required just after harvest for high protective activity, whatever the method and time of application. During the first year, average daily temperatures before harvest were between 18 and $25^{\circ} \mathrm{C}$. Dry weather was observed at the orchard except for one heavy rainfall lasting $10 \mathrm{~h}$ with a maximal intensity of $1.41 / \mathrm{m}^{2} \mathrm{~h}^{1}$ The relative humidity remained high (93-100\%) from 12 to 5 days before harvest. During the second year, temperatures were lower, ranging from 12 to $19^{\circ} \mathrm{C}$. The weather was rainy, with four heavy rainfall events (up to $5 \mathrm{~lm}-2 \mathrm{~h}-1)$. Rain might wash off a $\mathrm{BCA}$ during the first year. Furthermore, as strain $\mathrm{K}$ development is temperature-dependent with an optimum between 20 and $25^{\circ} \mathrm{C}$ (Lahlali 2006), the lower temperature range observed in the second year might have hindered development of the strain $\mathrm{K}$ population. In the case of pre-harvest biological treatments, variations in meteorological conditions between the 2 years have considerably affected strain $\mathrm{K}$ population density and its efficacies (Lahlali et al. 2009). These results were in accordance with the predictive models previously established (Lahlali et al. 2008a, b).

\section{Integration of strain $\mathrm{K}$ with control measures}

The complete substitution of pesticides by biological control does not constitute a realistic goal. Biological control must be considered like a new potential strategy to be integrated to a panel of other methods. In this respect, the compatibility of BCAs treatments must be firstly evaluated with regard to their integration to the succession of fruit conditioning operations before storage.

A first strategy to widen the spectrum of antagonistic action consists in mixing several BCAs (Nunes et al. 2002; Janisiewicz 1996). The combining of the $\mathrm{BCA}$ treatment with fungicides (Chandgoyal and Spotts 1996), organic (El Gaouth et al. 2000; Jijakli et al. 2002) and inorganic additives (Jijakli et al. 1999; Nunes et al. 2002) constitutes a second approach. The combination of chemical treatments with BCAs was more efficient than the application of the sole antagonistic microorgansism. The success of biocontrol integration to chemical treatments will depend on the selection of the best combinations of fungicide-antagonist In some cases, the combination of biological and chemical applications allowed the reduction of chemical concentration (Droby et al. 1993).The integration of the biological agents to other physical measures (thermotherapy, gamma and UV irradiation, film-forming polymers treatments) could be another solution to widen the spectrum of activity of BCAs (Leverentz et al. 2000; Jijakli and Lepoivre 2004). The control of infections due to Gloeosporioides fungi developing post-harvest apple rots from orchard latent infections, has to be assumed on post-harvest apples in addition to the protection of wound pathogens (Botrytis and Penicillium) (Jijakli and Lepoivre 1995). Heat treatment appeared to be efficient against Gloeosporioides lenticel infections (Bondoux 1992).

During a first year of trials, Golden Delicious fruits were successively dipped for $10 \mathrm{~min}$. in water at $45^{\circ} \mathrm{C}$ and $2 \mathrm{~min}$. in a water suspension of $P$. anomala strain $\mathrm{K}$ and $C$. oleophila strain $\mathrm{O}$. The incidence of Gloeosporioides lenticel infections was reduced from $54.4 \%$ to $1.5 \%$ and Penicillium maintained to a low level (Jijakli et al. 1993a). During a second year of trials, combination of heat treatment and yeast application could entirely control infections caused by $B$. cinerea and Gloeosporioides rot and the percentage of apples rotted by Penicillium spp. was reduced from $18.2 \%$ (untreated apples) to $3.8 \%$ (Jijakli et al. 1993a). During both years, quality parameters of treated apples (weight, size, skin color, firmness, acidity and refractometric index) were not affected. Nevertheless, the evaluation of the practical feasibility of an integrated approach combining $P$. anomala strain $\mathrm{K}$ and thermotherapy must be further studied.

\section{Registration of BCAs: no longer a drawback?}

Registration of a BCA is necessary before its commercialisation. In Europe, the directive CEE/91/ 414 , amended by the directive CE/2001/36 (specifically dealing with BCAs) is applied since 1993. The technical registration dossier of a BCA must provide information necessary concerning the foreseeable risks that this substance can create for human health and environment. The cost of the procedure is relatively high and depends on the microorganism, knowledge already generated on that microorganism, 
the results of the first toxicological tests and the presence of metabolites. At least 3 years are necessary before the first authorisation of sales in one of the European countries (an average of more than 50 months was recently recorded). In contrast, the United States has since 1980 a single legislation for the commercialisation and the use of biopesticides. The Agency of Environmental Protection (EPA) encourages the development and the use of these biopesticides. The EPA considers a priori that the use of those involves less risks than that of the conventional pesticides. Thus, in general, the data required for the registration are fewer and the procedure takes a minimum of one year and a half (an average of 24 months was recently recorded) whereas it is an average of more than 3 years for the recording of conventional pesticides. A novel European regulation (Regulation (EC) No 1107/2009 of the European Parliament and of the Council) is now coming into force. One can hope that it will go towards a lightening of the registration procedures.

\section{Conclusions}

The science and practice of biological control agents is still in its infancy compared to fungicidal treatment, even if progress made in this area during the past two decade has been remarkable. Many challenges must be met before biocontrol of post-harvest diseases can be successfully used on a commercial basis. Biological control is often generating a great enthusiasm although the still limited relevance of BCA today. The post-harvest environment may be one in which the best chance to develop successful biological control exists because many aspects of it can be controlled. Moreover, consumer demand for alternatives to post-harvest chemical treatments constitutes a major and special impetus in the search for biocontrol agents. Already commercially available products demonstrate the realism of the approach. However, encouragement from environmental agencies and central government remain crucial in determining the economic climate within which biological control will operate. This is particularly true considering registration process.

Twenty years of research on $P$. anomala strain $\mathrm{K}$ has led to a better characterisation of this strain in relation with its antagonistic activity against post- harvest diseases of apples. Thanks to increasing knowledge on that strain, several trials have demonstrated its potential application both in pre- and postharvest practical conditions. Moreover, $P$. anomala strain $\mathrm{K}$ may constitute a significant part of integrated systems including physical treatments or chemicals to provide adequate control of post-harvest diseases.

In the long term, basic information on the genetically determined factors that control survival, colonisation, effectiveness in the field and storage and properties of mass production are still required to overcome the random process of selection and to facilitate the practical development of such a method (Jijakli et al. 1999). This information will help in finding how to (1) further enhance the protective action of $P$. anomala, (2) protect its viability and performance under unfavourable environmental conditions, (3) ensure a good stability of the product during storage prior to application, and (4) provide a user-friendly product that is easy to apply.

\section{References}

Aloi C, Benzi D, Testoni A, Gullino ML (1991) Biological control of post-harvest diseases of apple : experimental results. In : ANPP-Third International Conference on Plant Diseases, Tome II. Ministère de l'Agriculture et Ministère de la Recherche et de la Technologie, Bordeaux, pp 695-702

Andrews JH (1992) Biological control in the phyllosphere. Annu Rev Phytopathol 30:603-635

Benbow JM, Sugar D (1999) Fruit surface colonization and biological control of post-harvest diseases of pear by preharvest yeast applications. Plant Dis 83:839-844

Bondoux P (1992) Maladies de conservation des fruits à pépins, pommes et poires. INRA and PHM revue Horticole, Paris

Chalutz E, Droby S, Cohen L, Weiss B, Barkai-Golan R, Daus A, Fushs Y (1991) Biological control of Botrytis, Rhizopus and Alternaria rots of tomato fruit by Pichia guillermondii. In : Proccedings of an International workshop on biological control of post-harvest diseases of fruits and vegetables, USA-USDA Publ. ARS-92, Shepherdstown, pp 71-85

Chandgoyal T, Spotts RA (1996) Post-harvest biological control of blue mold of apple and brown rot of sweet cherry by natural saprophytic yeast's alone or in combination with low doses of fungicides. Biol Control 6:253-259

Conway WS (1991) Post-harvest calcium treatment of apple fruit to provide broad-spectrum protection against postharvest pathogens. Plant Dis 75:620-622

De Clercq D, Cognet S, Pujol M, Lepoivre P, Jijakli MH (2003) Development of a SCAR marker and a 
semi-selective medium for specific quantification of $P i$ chia anomala strain $\mathrm{K}$ on apple surface. Postharvest Biol Technol 29:237-247

Droby S, Chalutz E, Wilson CL, Wisniewski M (1989) Characterization of the biocontrol activity of Debarryomyces hansenii in the control of Penicillium digitatum on grapefruit. Can J Microbiol 35:308-313

Droby S, Chalutz E, Horev B, Cohen L, Gaba V, Wilson CL, Wisniewski ME (1993) Factors affecting UV-induced resistance in grapefruit against the green mould decay caused by Penicillium digitatum. Plant Pathol 42:418-424

El Gaouth AE, Wilson C,Wisniewski M (2000) Induction of systemic resistance in apple by the yeast antagonist, Candida saitoana. In: Biocontrol Agents : Mode of Action and their Interaction with Other Means of Control. 6th IOBC wprs Biocontrol Workshop, Sevilla, p 80

Elad Y (1990) Reasons for delay in development of biological control of rose and foliar pathogens. Phytoparasitica 18:99-105

Friel D, Vandenbol M, Jijakli MH (2003) Cloning and sequence analysis of the TRPI gene encoding the phosphoribosyl anthranilate isomerase from Pichia anomala (strain K). Yeast 20:1331-1337

Friel D, Vandenbol M, Jijakli MH (2005) Genetic characterization of the yeast Pichia anomala (strain $\mathrm{K}$ ) an antagonist of postharvest diseases of apple. J Appl Microbiol 98:783-788

Friel D, Gomez Pessoa N, Vandenbol M, Jijakli MH (2007) Separate and combined disruptions of two exo-b-1. 3-glucanase genes decrease the efficiency of Pichia anomala (strain K) biocontrol against Botrytis cinerea on apples. Mol Plant Microbe Interact 20:371-379

Grevesse C, Lepoivre P, Jijakli MH (2003) Characterization of the exoglucanase-encoding gene PaEXG2 and study of its role in the biocontrol activity of Pichia anomala Strain $\mathrm{K}$. Phytopathology 93:1145-1152

Gullino ML, Aloi C, Benzy D, Garibaldi A (1991) Attempts at biological control of post-harvest diseases of apple. Med Fac Landbouw Univ Gent 56:195-202

Harper AM, Strange RN, Langcake P (1981) Characterization of the nutriments required by Botrytis cinerea to infect broad bean leaves. Physiol'Plant Pathol 19:153-167

Ippolito A, Nigro F (2000) Impact of pre-harvest application of biological control agents on post-harvest diseases of fresh fruits and vegetables. Crop Protection 19:715-723

Janisiewicz W (1988) Biocontrol of post-harvest diseases of apples with antagonist mixtures. Phytopatology 78 : 194-198

Janisiewicz W (1991) Biological control of post-harvest fruit diseases. In: Arora DK, Rai B, Mukerji KG, Knudsen GR (eds) Handbook of Applied Mycology, Volume 1. Marcel Dekker Inc., New York, pp 301-325

Janisiewicz W (1994) Enhancement of biocontrol of blue mold with the nutrient analog 2-deoxy-d-glucose on apples and pears. Appl Environ Microbiol 60:2671-2676

Janisiewicz W (1996) Ecological diversity, niche overlap, and coexistence of antagonists used in developing mixtures for biocontrol of post-harvest diseases of apples. Phytopathology 86:473-479

Janisiewicz W, Kosten L (2002) Biological control of Postharvest diseases of fruits. Annu Rev Phytopathol 40: $411-441$
Janisiewicz W, Roitman J (1988) Biological control of blue mold and gray mold on apple and pear with Pseudomonas cepacia. Phytopathology 78:1697-1700

Janisiewicz W, Usall J, Bors B (1992) Nutritional enhancement of biocontrol of blue mold on apples. Phytopatology 82:1364-1370

Jejelowo OA, Epton HAS, Trinci APJ (1988) Effects of paramorphogens and 2-deoxy-d-glucose on development of lesions of Botrytis fabae on Vicia faba. Trans Br Mycol Soc 91:661-669

Jijakli MH, Lepoivre P (1993) Biological control of post-harvest Botrytis cinerea and Penicillium on apples. IOBC WPRS Bulletin 16:106-110

Jijakli MH, Lepoivre P (1995) Utilisation de biopesticides pour la protection des pommes en conservation. Le Fruits Belge 445:83-88

Jijakli MH, Lepoivre P (1998) Characterization of an exo- $\beta-1$, 3-glucanase produced by Pichia anomala strain K, antagonist of Botrytis cinerea on apples. Phytopathology $88: 335-343$

Jijakli MH, Lepoivre P (2004) State of the art and challenges of post-harvest diseases management in apples. In: Mukerji KG (ed) Disease Management of Fruits and Vegetables, Vol.1: Fruit and Vegetable Diseases. Kluwer Academic Publisher, Boston, pp 59-94

Jijakli MH, Lepoivre P, Tossut P, Thonart P (1993a) Biological control of Botrytis cinerea and Penicillium on post-harvest apples by two antagonistic yeasts. Med Fac Landbouw Univ Gent 58:1349-1358

Jijakli MH, Choutka C, Lepoivre P (1993b) Formulation and integrated use of two antagonistic yeasts to postharvest treatments against diseases on apples. In: P. Lepoivre (ed) Biological control of fruit and foliar disease. Proceedings of an EC workshop, Gembloux, pp 107-117

Jijakli MH, Lepoivre P, Grevesse C (1999) Yeast species for biocontrol of apple post-harvest diseases: an encouraging case of study for practical use. In: Mukerji KG, Chamola BP, Upadhyay RH (eds) Biotechnological approaches in biocontrol of plant pathogens. Kluwer Academic Publisher, Boston, pp 31-49

Jijakli MH, De Clercq D, Dickburt C, Lepoivre P (2002) Preand post-harvest practical application of Pichia anomala strain $\mathrm{K}, \beta-1,3$-glucans and calcium chloride on apples : two years of monitoring and efficacy against post-harvest diseases. IOBC/WPRS Bulletin 25:29-32

Korsten L, De Villiers EE, Wehner FC, Kotz'e JM (1997) Field sprays of Bacillus subtilis and fungicides for control of pre-harvest fruit diseases of avocado in South Africa. Plant Dis 81:455-459

Lahlali R (2006) Etude et modélisation du comportement écologique de deux agents pathogènes de conservation des pommes $P$. expansum Link et $B$. cinerea Pers. et deux de levures Pichia anomala (souche K) et Candida oleophila (souche $\mathrm{O}$ ) antagonistes vis-à-vis de ces pathogènes des pommes en conservation. Dissertation, University of Liège, Gembloux Agro Bio-Tech

Lahlali R, Bajji M, Serrhini MN, Jijakli MH (2008a) Modelling the effect of temperature, water activity and solute on the in vitro growth of the biocontrol yeast Pichia anomala strain K. Biotechnol Agron Soc Environ 12:353-359 
Lahlali R, Massart S, Serrhini MN, Jijakli MH (2008b) A BoxBehnken design for predicting the combined effects of relative humidity and temperature on antagonistic yeast population density at the surface of apples. Int J Food Microbiol 122:100-108

Lahlali R, Massart S, De Clercq D, Serrhini MN, Creemers P, Jijakli MH (2009) Assessment of Pichia anomala (strain K) efficacy against blue mould of apples when applied pre-or post-harvest under laboratory conditions and in prerd trials. Eur J Plant Pathol 123:37-45

Lahlali R, Brostaux Y, Jijakli MH (2011) Control of apple blue mold by the antagonistic yeast Pichia anomala strain K: screening of UV-protectants for pre-harvest application. Plant Diseases, doi:10.1094/PDIS-04-10-0265

Leibinger W, Breuker B, Hahn M, Mendgen K (1997) Control of post-harvest pathogens and colonization of the apple surface by antagonistic microorganisms in the field. Phytopathology 7:1103-1110

Leverentz B, Janisiewicz W, Conway WS, Saftner RA, Fuchs Y, Sams CE, Camp MJ (2000) Combining yeasts or a bacterial biocontrol agent and heat treatments to reduce post-harvest decay of 'Gala' apples. Postharvest Biol Technol 21:87-94

Magan N (2001) Physiological approaches to improving the ecological fitness of fungal biocontrol agents, fungi as biocontrol agents. progress, problems and potential. CABI Publishing, Bristol

Massart S, Jijakli MH (2006) Identification of differentially expressed genes by cDNA-amplified fragment length polymorphism in the biocontrol agent Pichia anomala (strain Kh5). Phytopathology 96:80-86

Massart S, De Clercq D, Salmon M, Dickburt C, Jijakli MH (2005) Development of real-time PCR using Minor Groove Binding probe to monitor the biological control agent Candida oleophila (strain O). J Microbiol Meth 60:73-82

McGuire RG (1994) Application of Candida guilliermondii in commercial citrus coatings for biocontrol of Penicillium digitatum on grape fruits. Biol Control 4:1-7

McLaughlin RJ, Wisniewski ME, Wilson CL, Chalutz E (1990) Effect of inoculum concentration and salt solutions on biological control of post-harvest diseases of apple with Candida sp. Phytopathology 80:456-461

Messiaen J (1994) La transduction du signal chez les végétaux supérieurs en réponse à une attaque pathogène : Identification de réponses membranaires, cytosoliques et nucléaires induites par des olgogalacturonides. Dissertation, University of Namur

Nunes C, Usall J, Teixido N, Abadias M, Vinas I (2002) Improved control of post-harvest decay of pears by the combination of Candida sake (CPA-1) and ammonium molybdate. Phytopathology 92:281-287

Olive M, Bean P (1999) Principles and applications of methods for DNA-based typing of microbial organisms. J Clin Microbiol 37:1661-1669

Pujol M, De Clercq D, Cognet S, Lepoivre P, Jijakli MH (2004) Monitoring system for the biocontrol agent Pichia anomala strain $\mathrm{K}$ using quantitative competitive PCRELOSA. Plant Pathol 53:103-109

Roberts RG (1991) Post-harvest biological control of gray mold of apple by Cryptococcus laurentii. Phytopathology 80:1051

Schnïrer J, Jonsson A (2011) Pichia anomala J121: a 30-year overnight near success biopreservation story. Antonie van Leewwenhoek doi:10.1007/s10482-010-9509-2

ixidõ N, Vinãs I, Usall J, Sanchis V, Magan N (1998) Ecophysiological responses of the biocontrol yeast of Candida sake to water, temperature and $\mathrm{pH}$ stress. J Appl Microbiol 84:192-200

Teixidõ N, Usall J, Viñas I (1999) Efficacy of pre-harvest and post-harvest Candida sake biocontrol treatments to prevent blue mould on apples during cold storage. Int J Food Microbiol 50:203-210

Wilson CL, Wisnieswski ME (1994) Biological Control of Post-harvest Diseases: Theory and Practice. CRC Press, London

Wilson CL, Wisniewski ME (1989) Biological control of postharvest diseases of fruits and vegetables : an emerging technology. Annu Rev Phytopathol 27:425-441

Wilson CL, Wisniewski ME, Droby S, Chalutz E (1993) A selection strategy for microbial antagonists to control post-harvest diseases of fruits and vegetables. Sci Hortic 53:183-189

Wisniewski ME, Wilson CL, Hershberger WS (1989) Characterization of inhibition of Rhyzopus stolonifer germination and growth by Enterobacter cloacea. Can J Bot 67:2317-2323

Wisniewski M, Biles C, Droby S, McLaughlin R, Wilson C, Chalutz E (1991) Mode of action of the post-harvest biocontrol yeast, Pichia guillermondii. I. Characterization

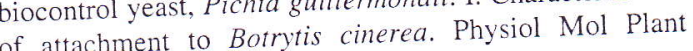
Pathol 39:245-258 